Nikitovic, J., Andrijasevic, D., Krajisnik, T., Antic, M., Kajkut Zeljkovic, M., Samardzic, S., Stojanovic, M. (2021): Morphometric measures of the Gatacko cattle on the territory of Gacko municipality. Agriculture and Forestry, 67 (3): 159-166

DOI: 10.17707/AgricultForest.67.3.13

\begin{abstract}
Jelena NIKITOVIC ${ }^{1}$, Dusan ANDRIJASEVIC ${ }^{2}$, Tatjana KRAJISNIK ${ }^{3}$, Marina ANTIC ${ }^{l}$, Mirela KAJKUT ZELJKOVIC ${ }^{l}$, Slavica SAMARDZIC ${ }^{4}$, Mladen STOJANOVIC ${ }^{4}$
\end{abstract}

\title{
MORPHOMETRIC MEASURES OF THE GATACKO CATTLE ON THE TERRITORY OF GACKO MUNICIPALITY
}

\section{SUMMARY}

Gatacko cattle, as one of the indigenous breeds of the Bosnia and Herzegovina, namely its entity of Republic of Srpska, deserve special attention when it comes to detailed description of the breed, inventory and genotyping. This kind of research is apsolutely neccesary in order to establish programs for in citu preservation of genetic resources. As the name of the breed suggests, Gacko municipality is the most relevant for this breed in terms of breeding and the total number of cattle, and was therefore selected for our research.

The aim of this paper was to determine morphometric parameters of the Gatacko cattle by conducting appropriate measurements. The study involved 288 cows, and the total of 15 parameters were measured on each cow. The analysis of obtained data was performed using methods of desciptive statistical analysis. Also, the phenotypic correlation between the morphometric parameters was calculated.

The results indicates higher values of all morphometric parameters, except for the shin girth. The contribution of this research is reflected in a large number of samples on which morphometric characterization were performed and correlations determined, which provide material for further research towards genotyping of this indigenous breed and establishing the breeding goals.

Keywords: Gatacko cattle, morphometric parameters, phenotypic correlation

\footnotetext{
${ }^{1}$ Jelena Nikitovic (corresponding author: jelena.nikitovic@igr.unibl.org), Marina Antic, Mirela Kajkut Zeljkovic, University of Banja Luka, Institute for Genetic Resources, Bulevar vojvode Petra Bojovica 1a, 78000 Banja Luka, BOSNIA AND HERZEGOVINA

${ }^{2}$ Dusan Andrijasevic, Municipality of Gacko, Solunskih dobrovoljaca 2, 89240 Gacko, BOSNIA AND HERZEGOVINA

${ }^{3}$ Tatjana Krajisnik, University of East Sarajevo, Faculty of Agriculture, Vuka Karadzica 30, 71123 East Sarajevo, BOSNIA AND HERZEGOVINA

${ }^{4}$ Slavica Samardzic, Mladen Stojanovic, Ministry of Agriculture, Forestry and Water Management of Republic of Srpska, Trg Republike Srpske 1, 78000 Banja Luka, BOSNIA AND HERZEGOVINA

Notes: The authors declare that they have no conflicts of interest. Authorship Form signed online. 


\section{INTRODUCTION}

The homeland of Gatacko cattle is a mountainous region of Gacko municipality in East Herzegovina, with average altitude of more than $1000 \mathrm{~m}$, with continental climate and average temperature of just $8^{\circ} \mathrm{C}$. At the time when Bosnia and Herzegovina were annexed by Austro-Hungarian monarchy (1878), the cattle breeding in Herzegovina was based on Busha cattle, a small cow with a mass of just $200 \mathrm{~kg}$, but resilient and well adapted to climate. As the new government wanted a larger cattle, with better production of milk, but still able to withstand harsh condition, it was decided to cross-breed the Busha cattle with Viptal and Oberintal cattle, to create a new breed, the Gatacko cattle.

The Gatacko cattle are short-legged cattle, short-headed, with wide and uneven forehead. The muzzle is darkly pigmented with light edge. The horns are thin and pointed forward. Basic color is gray, but it can also be brown with dark shading on certain parts of the body. Cows have body mass around $400 \mathrm{~kg}$, while bull's weight is around $750 \mathrm{~kg}$. The Gatacko cattle are most valued for its milk production, which can goes up to 2,500 1 per year (Katica et al., 2004).

Considering that the overall decrease of cattle population has been recorded in the Republic of Srpska and Bosnia and Herzegovina, it is quite understandable that the same has happened regarding indigenous breed of Gatacko cattle (The Law on Cattle Breeding, Official Gazette of the Republic of Srpska, No 44/15, article 40, and paragraph 2). The importance of indigenous breeds of domestic animal is indisputable. These breed, and thus the Gatacko cattle, influence the revitalization of rural areas by generating additional income for the local population. As the Gatacko cattle are well adapted to the local climate and terrain, they help maintain pasture areas, preventing the devastation and succession of habitats (biotopes).

The Gatacko cattle is recognized as endangered breed, therefore it is absolutely necessary to conduct inventory and morphometric measurements of potentially autochthonous individuals, followed by genotyping. All individual cows and bulls, confirmed as indigenous, will be involved in project of conservation of Gatacko cattle in order to preserve its gene pool. Morphometric measurements presented in this paper are part of broader activities aimed on revitalization of Gatacko cattle.

\section{MATERIAL AND METHODS}

The aim of this paper was to determine morphometric parameters (15 of them) of indigenous breed Gatacko cattle, on the area of municipality Gacko, Republic of Srpska - Bosnia and Herzegovina. Additional aim was to determine the variability of the mean value of examined parameters, indices of body measures in relation to the height at withers, correlation between the examined parameters and the significance of the calculated correlation coefficients. The morphometric measurements, for purpose of the morphometric characterization of the Gatacko cattle, was performed on 288 cows, all females, as there were only 
few bulls found in the field. Moreover, the morphometric measurements of the bulls are quite different to cows, so they were omited in this research. Based on the registry (ear tag), and the statement of the owners, the age of each cow was defined, and no cow was younger than 2 years at the time of this research. The measurements were conducted at the begining of the year 2021 on the following localities: Miholjace, Vratkovici, Stari Dulici, Novi Dulici, Dobrelja, Gareva, Samobor, Mala Gareva, Domrke, Gradina, Mume, Lukovice, Medanici, Nadanici, Stepen, Przine, Cernica, Danici, Krvarevo and Fojnica, all belonging to municipality Gacko.

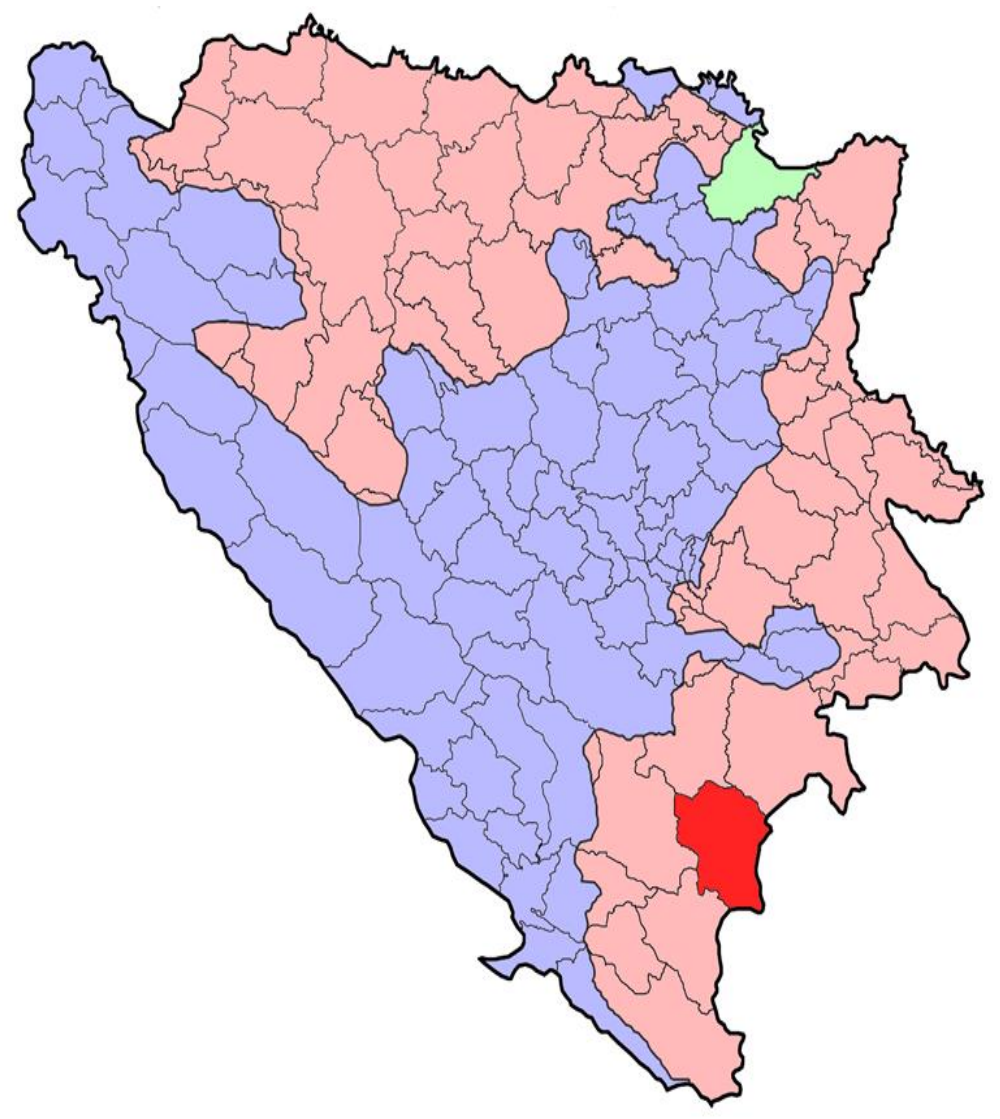

Picture 1. The territory of municipality Gacko (marked red) on the map of Bosnia and Herzegovina and Republic of Srpska (marked pink)

The following morphometric parameters were measured on each cow: Height at withers (HW), back height (BH), loin height (LH), body length (BL), chest width $(\mathrm{CW})$, chest depth $(\mathrm{CD})$, chest girth (CG), hip width (HW), pin bones 
width (PBW), front shin girth (FSG), back shin girth (BSG), head length (HL), forehead width (FW), horn length (HNL), horn girth (HNG). Morphometric measurements were performed using ribbon and Lydtin`s rod (Lalovic and Zdralic, 2018).

In addition to absolute body measures, the relative indicators of physical development, ie indices, were calculated. The body indices represent the ratio of one measured body parameter to another, in this case to the height at withers. The indices were calculated according to Alderson (1999). The obtained results were processed using the software Microsoft Office Excel 2010, and the phenotypic correlation between the morphometric parameters was determined (R Core Team, 2015). Descriptive statistic values were calculated: coefficient of variation (CV), standard error (SE), standard deviation (SD), minimum value (MIN), maximum value (MAX), mean value $(\overline{\mathrm{x}})$ and indices in relation to height at withers (I). As statistically significant were taken differences $\mathrm{P}<0.05$.

\section{RESULTS AND DISCUSSION}

A phenotypic characterization of any breed can not be done without morphometric characterization. Performing this characterization is necessary in order to bring decisions about development of the breed and its breeding programs (FAO, 2012). Morphometric characterization of the Gatacko cattle is conducted on 15 body parameters.

Values of morphometric parameters in examined Gatacko cattle are shown in Table 1.

Table 1. Average variability of body parameters in Gatacko cattle

\begin{tabular}{|c|c|c|c|c|c|c|}
\hline Parameter (in cm) & $\overline{\boldsymbol{x}} \pm$ SD & SE & CV & I* & Min & Max \\
\hline Height at withers (HW) & $133.00 \pm 2.99$ & 0.18 & 2.25 & 1.00 & 120.00 & 156.00 \\
\hline Back height (BH) & $131.80 \pm 3.05$ & 0.18 & 2.31 & 0.99 & 119.00 & 155.00 \\
\hline Loin height (LH) & $132.60 \pm 2.89$ & 0.17 & 2.18 & 0.10 & 120.00 & 155.00 \\
\hline Body length (BL) & $156.40 \pm 5.25$ & 0.31 & 3.36 & 1.18 & 130.00 & 173.00 \\
\hline Chest width (CW) & $64.30 \pm 5.65$ & 0.33 & 8.79 & 0.48 & 42.00 & 72.00 \\
\hline Chest depth (CD) & $78.40 \pm 5.70$ & 0.34 & 7.27 & 0.60 & 45.00 & 88.00 \\
\hline Chest girth (CG) & $183.60 \pm 6.66$ & 0.40 & 3.63 & 1.38 & 165.00 & 233.00 \\
\hline Hip width (HW) & $61.40 \pm 2.20$ & 0.13 & 2.80 & 0.46 & 47.00 & 73.00 \\
\hline Pin bones width (PBW) & $42.90 \pm 2.77$ & 0.16 & 6.46 & 0.32 & 23.00 & 51.00 \\
\hline Front shin girth (FSG) & $13.70 \pm 0.99$ & 0.06 & 7.23 & 0.10 & 12.00 & 20.00 \\
\hline Back shin girth (BSG) & $13.10 \pm 1.00$ & 0.06 & 7.63 & 0.09 & 10.00 & 18.00 \\
\hline Head length (HL) & $47.50 \pm 1.78$ & 0.10 & 3.75 & 0.36 & 40.00 & 52.00 \\
\hline Forehead width (FW) & $24.20 \pm 1.66$ & 0.09 & 6.86 & 0.18 & 14.00 & 29.00 \\
\hline Horn length (HNL) & $13.80 \pm 2.47$ & 0.15 & 17.40 & 0.10 & 7.00 & 25.00 \\
\hline Horn girth (HNG) & $11.80 \pm 1.48$ & 0.09 & 12.54 & 0.09 & 9.00 & 16.00 \\
\hline
\end{tabular}

*Indices in relation to the height at withers 
The average height at withers was $133.00 \pm 2.99$, and interval of variation between $120 \mathrm{~cm}$ and $156 \mathrm{~cm}$. Those values are similar to research by Varatanovic (2018) who examined three different groups of cow and found the mean value of this parameter $5.59 \mathrm{~cm}, 5.92$ and $2.88 \mathrm{~cm}$ different to our research. Gutic et al. (2003) in their research on 125 cows found this parameter only $122.71 \mathrm{~cm}$ on average. The mean value for back height on our examined Gatacko cattle was $131.80 \mathrm{~cm}$ with standard deviation (SD) of 3.05 and variation interval from 119 $\mathrm{cm}$ to $155 \mathrm{~cm}$, while the coefficient of variation $(\mathrm{CV})$ was $2.31 \%$. When it comes to loin height, mean value was $132.60 \mathrm{~cm}$, with interval of variation from $120 \mathrm{~cm}$ to $155 \mathrm{~cm}$, and coefficient of variation $2.18 \%$. The loin height in the research of Varatanovic (2018) on three groups was similar to our results $(128.83 \mathrm{~cm}, 130.88$ $\mathrm{cm}$ and $134.00 \mathrm{~cm})$. Comparing to the work of Ilancic (1952) and Gutic et al. (2003), we can conclude that our results for this parameter are around $10 \mathrm{~cm}$ higher. The average body length in examined cows was $156.40 \mathrm{~cm}$, with variation interval from $130 \mathrm{~cm}$ to $173 \mathrm{~cm}$, and coefficient of variation $3.36 \%$. Gutic et al. (2003) found this parameter slightly higher with average value of $159.30 \mathrm{~cm}$ and interval of variation from $144 \mathrm{~cm}$ to $171 \mathrm{~cm}$, while Varatanovic (2018) found body length at $142.56 \mathrm{~cm}$ on average. The mean value for the chest depth in our examined cows was $78.40 \mathrm{~cm}$ with interval of variation from $45 \mathrm{~cm}$ to $88 \mathrm{~cm}$. Gutic et al. (2003) found the mean value of this parameter at $67.45 \mathrm{~cm}$, which is significantly lower than our results. The chest girth in our research was 183.60 $\mathrm{cm}$ on average, which is almost identical to Varatanovic (2018), and $14.71 \mathrm{~cm}$ higher than Gutic et al. (2003). Other authors also found lower results for this parameter. Pajanovic (1961) compared this parameter for three different locations, and found that cows from Gacko have chest girth $151.41 \mathrm{~cm}$ on average, from Nevesinje $147.25 \mathrm{~cm}$, and from Kalinovik $148.07 \mathrm{~cm}$. Sucic et al. (1978) found the mean value of this parameter at $160.70 \mathrm{~cm}$, while Popovic et al. (1979) found the mean value of $166.20 \mathrm{~cm}$. The hip width in our examined cows was $61.40 \mathrm{~cm}$ on average, which is $9.36 \mathrm{~cm}$ higher than value found by Gutic et al. (2003). When it comes to the front shin girth we have found mean value at $13.70 \mathrm{~cm}$, while the mean value of the back shin girth was $13.10 \mathrm{~cm}$. Morphometric parameters of the head was on average $47.50 \mathrm{~cm}$ for the head length, $24.20 \mathrm{~cm}$ for the forehead width, $13.80 \mathrm{~cm}$ for the horn length and 11.80 $\mathrm{cm}$ for the horn girth. Coefficients of variation (CV) for 13 out of 15 measured paremeters ranged from $2.18 \%$ (loin height) to $8.79 \%$ (chest width). Only the horn length $(17.40 \%)$ and horn girth $(12.54 \%)$ have higher coefficient of variation, which can be explained by cow`s minor moving during measurements, and should be taken with reserve when making conclusions about this parameters.

The correlation of average values of examined body parameters, as well as statistical significance of correlations is shown in table 2.

Height at withers $(\mathrm{HW})$ is in very highly positive correlation $(\mathrm{P}<0.001)$ with all examined parameters, except for the back shin girth $(\mathrm{P}<0.05)$, and horn length and girth, where the correlation is highly significant $(\mathrm{P}<0.01)$. 
Table 2. Phenotypic correlations of morphological characteristics of the Gatacko cattle

\begin{tabular}{|c|c|c|c|c|c|c|c|c|c|c|c|c|c|c|}
\hline 密 & $\begin{array}{l}\text { 葹 } \\
0\end{array}$ & 罢 & 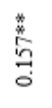 & $\begin{array}{l}\text { co: } \\
\text { d. }\end{array}$ & 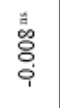 & $\begin{array}{l}\text { : } \\
\text { : }\end{array}$ & 尊 & 萑 & 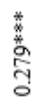 & 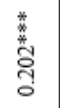 & 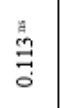 & $\begin{array}{l}\text { 总 } \\
\text { o. }\end{array}$ & 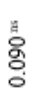 & 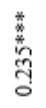 \\
\hline 忘 & 善 & $\begin{array}{l}\stackrel{*}{\vec{a}} \\
0 \\
0\end{array}$ & 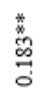 & $\frac{*}{\sigma}$ & $\begin{array}{l}\text { 产 } \\
\end{array}$ & 岂 & & $\begin{array}{l}\text { 蒡 } \\
\text { 。 }\end{array}$ & 啇 & $\begin{array}{l}\stackrel{y}{y_{0}^{\prime}} \\
\stackrel{0}{0}\end{array}$ & 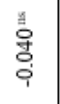 & 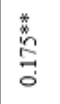 & $\begin{array}{l}\text { 美 } \\
\stackrel{0}{0}\end{array}$ & \\
\hline 屈 & $\begin{array}{l}\text { 蒡 } \\
\text { 京 } \\
\text { d }\end{array}$ & $\begin{array}{l}\text { 蒡 } \\
\text { à } \\
\text { à }\end{array}$ & 范 & $\begin{array}{l}\text { 葆 } \\
\text { तु }\end{array}$ & 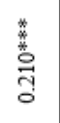 & 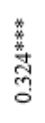 & 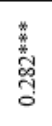 & 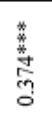 & 蒌 & 品 & 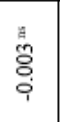 & $\begin{array}{l}\text { : } \\
\text { : } \\
\text { : }\end{array}$ & & \\
\hline 目 & 蒡 & $\begin{array}{l}\underset{D}{*} \\
\stackrel{*}{0}\end{array}$ & 善 & 蒌 & 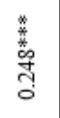 & สู สู & 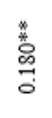 & 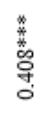 & $\stackrel{\text { : }}{\Xi}$ & $\begin{array}{l}0 \\
\text { an } \\
0 \\
0\end{array}$ & $\begin{array}{l}\text { 参 } \\
\text { o. }\end{array}$ & & & \\
\hline 㟔 & 总 & $\begin{array}{l}\text { 厸 } \\
\text { og }\end{array}$ & స્. & 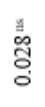 & 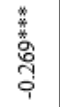 & $\frac{\text { 寺 }}{\stackrel{*}{9}}$ & 意 & 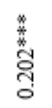 & 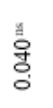 & 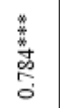 & & & & \\
\hline 总 & 茧 & 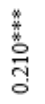 & 蒡 & 莕 & 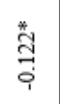 & $\begin{array}{l}\text { h. } \\
\text { ho } \\
\text { on }\end{array}$ & 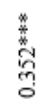 & 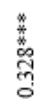 & $\stackrel{\text { }}{\stackrel{*}{2}}$ & & & & & \\
\hline 总 & 旁 & 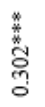 & $\begin{array}{l}\text { 絭 } \\
\text { d. }\end{array}$ & 葸 & 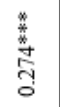 & $\begin{array}{l}\text { 嘋 } \\
\text { ă }\end{array}$ & 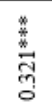 & 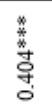 & & & & & & \\
\hline 触 & 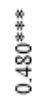 & 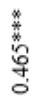 & 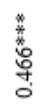 & 蒌 & $\begin{array}{l}\text { 䇏 } \\
\text { 誉 }\end{array}$ & 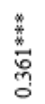 & 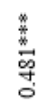 & & & & & & & \\
\hline ర্ঠ & $\begin{array}{l}\text { 糡 } \\
\text { 总 }\end{array}$ & 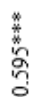 & $\begin{array}{l}\text { 棓 } \\
\text { o. } \\
\text { a. }\end{array}$ & 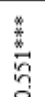 & $\begin{array}{l}\frac{*}{2} \\
\stackrel{\text { in }}{m}\end{array}$ & 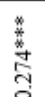 & & & & & & & & \\
\hline 8 & 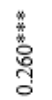 & 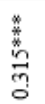 & $\begin{array}{l}\frac{*}{4} \\
\stackrel{4}{*} \\
\end{array}$ & 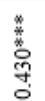 & 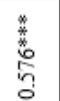 & & & & & & & & & \\
\hline E & 意 & 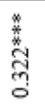 & $\begin{array}{l}\text { 榣 } \\
0\end{array}$ & 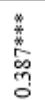 & & & & & & & & & & \\
\hline 岗 & 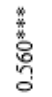 & 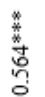 & 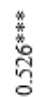 & & & & & & & & & & & \\
\hline 思 & 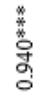 & 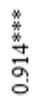 & & & & & & & & & & & & \\
\hline 思 & 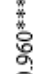 & & & & & & & & & & & & & \\
\hline & 展 & 出 & 出 & 岗 & B & 8 & 8 & 兑 & 总 & 品 & 号 & 旵 & 苫 & 㴈 \\
\hline
\end{tabular}


Back height $(\mathrm{BH})$ is in very highly significant correlation $(\mathrm{P}<0.001)$, highly significant $(\mathrm{P}<0.01)$ or significant $(\mathrm{P}<0.05)$ with most body parameters, while the significance was not confirmed $(\mathrm{P}>0.05)$ in correlation with back shin girth and horn girth. We can conclude the similar correlation of body length (BL), hip width (HW) and horn length (HNL) with other examined parameters in this paper. Loin height (LH) has statistically significant correlation with all examined parameters, at every level of significance. Chest width $(\mathrm{CW})$ has correlation significance at level $\mathrm{P}<0.001$ with most parameters, while the correlation to front shin girth (FSG) and back shin girth (BSG) is negative at levels $\mathrm{P}<0.05$ and $\mathrm{P}<0.001$, respectively. Similar results were found at correlations between chest depth (CD) and examined parameters, except for front shin girth (FSG) where no significance was found $(\mathrm{P}>0.05)$. Also, for both of these parameters (chest depth and width) the statistical significance to horn parameters (length and girth) was not confirmed ( $\mathrm{P}>0.05)$. Chest girth $(\mathrm{CG})$ has statistically positive significant correlation with all examined parameters, at every level of significance, except to horn length (HNL), where significance was not confirmed $(\mathrm{P}>0.05)$. Pin bones width is in statistically significant correlation front shin girth, forehead width and horn girth at levels $\mathrm{P}<0.05$ and $\mathrm{P}<0.001$, while statistical significance was not confirmed in correlation to back shin girth, head length and horn length $(\mathrm{P}>0.05)$. Front shin girth is in very highly significant correlation $(\mathrm{P}<0.001)$ with back shin girth and horn length, while the correlation of back shin girth to head length, forehead width and horn length are all negative and statistically not confirmed $(\mathrm{P}>0.05)$. Head length is in highly significant correlation $(\mathrm{P}<0.01)$ to forehead width and horn length, while the correlation of forehead width to horn parameters is not statistically confirmed $(\mathrm{P}>0.05)$.

\section{CONCLUSIONS}

A detailed morphometric description of Gatacko cattle is very important as a precondition to further analysis of the breed, genotyping, establishing the breeding program and setting the breeding goals. We have measured 15 body parameters on 288 cows from the territory of Gacko municipality in the Republic of Srpska - Bosnia and Herzegovina. We have also determined the variability of examined parameters, and the significance of correlation between the measured parameters.

Based on the obtained results from our research on Gatacko cattle, we can conclude that all body parameters have higher values (except for shin girth) than previous examinations of other authors. The reason for this may be found in mating selection, which is commonly based on phenotype characteristics of the cattle, and under the man's influence. Other reasons could be found in total number of examined cows, different breeding conditions and climate change in the last 50 years, when the previous research were performed.

The results from our research can be used for further detailed description of this breed. 


\section{ACKNOWLEDGEMENTS}

This paper is a result of project "Program of DNA typing of Gatacko cattle“ number 12.03.2-330-1567-1/20 from May, 27 ${ }^{\text {th }}$ 2020, financed and approved by Ministry of Agriculture, Forestry and Water Management of Republic of Srpska.

\section{REFERENCES}

Alderson G.L.H. (1999): The development of a system of linear measurements to provide an assessment of time and function of beef cattle. AGRI 25: 45-55.

FAO (2012): Phenotypic characterization of animal genetic resources. FAO Animal Production and Health Guidelines, No. 11.

Gutic M, Petrovic M, Bogosavljevic-Boskovic S, Lalovic M, Rajicic V. (2003): Efekat uzgojno-selekcijskog rada na postignute telesne dimenzije gatačkog govečeta. Agroznanje, Vol. 4, No.1: 21-29.

Ilancic D. (1952): Gatačko govedo-vrelo za oplemenjivanje naše Buše. Stočarstvo, Vol. 4, 145-156.

Katica V, Hadziomerovic Z, Salkic A, Sakic V, Softic A. (2004): Autohtone pasmine domaćih životinja u Bosni i Hercegovini. Promocult, Sarajevo, 171.

Lalovic M., Zdralic T. (2018): Stočarstvo - Ocjena eksterijera. Udžbenik, str. 166. Poljoprivredni fakultet Istočno Sarajevo.

Pajanovic R. (1961): Utjecaj sivo tirolskog goveda na tip goveda Sjeveroistočne Hercegovine. Radovi poljoprivrednog fakulteta, Vol. 10, No 12.

Popovic D, Vidovic Z, Nakic S. (1979): Pasminski sastav i tjelesna građa krava Opštine Mostar. Savjetovanje o problemima stočarstva brdsko-planinskog područja Jugoslavije. Mostar

R Core Team (2015): R: A language and environment for statistical computing. R Foundation for Statistical Computing, Vienna, Austria, https://www.R-project.org/

Sucic B, Djonlagic J, Grabovac B, Karailo M. (1978): Utjecaj sivo-tirolskih i smeđe alpskih bikova na pasminsku strukturu i tjelesno ustrojstvo krava Jugozapadne Bosne. Stočarstvo, Vol. 32, 367-376.

The Law on Cattle Breeding (2015): Službeni glasnik Republike Srpske, 21. maj 2015, $44 / 15$

Varatanovic M. (2018): Procjena genetičkog diverziteta gatačkog goveda u Bosni i Hercegovini u cilju zaštite pasmine, Doktorska disertacija, Univerzitet u Sarajevu, Veterinarski fakultet 